\begin{tabular}{|c|c|}
\hline $\begin{array}{l}\text { EXCELLENT } \\
\text { PUBLISHERS }\end{array}$ & $\begin{array}{c}\text { International Journal of Current Research in } \\
\text { Biosciences and Plant Biology } \\
\text { ISSN: 2349-8080 (Online) } \bullet \text { Volume } 3 \bullet \text { Number } 10 \text { (October-2016) }\end{array}$ \\
\hline
\end{tabular}

\title{
Influence of Plant Spacing on the Growth and Yield of Groundnut (Arachis hypogaea L.)
}

\author{
Hero Fatih Hamakareem*, Bekhal Mustafa Hamahasan and Sarkawt Hama Salih Ali
}

University of Sulaimani, Faculty of Agricultural Sciences, Bakrajo, Sulaimani, Iraq

*Corresponding author.

\begin{abstract}
The field experiments were conducted to evaluate the effect of three plant spacing $(50 \times 30 \mathrm{~cm}, 60 \times 30 \mathrm{~cm}$ and $70 \times 30 \mathrm{~cm})$ on the vegetative and yield parameters of groundnut (Arachis hypogaea L.). The experiments were conducted as a Randomized Complete Block Design (RCBD) during 2013 and the treatments were replicated three times. The results showed that vegetative parameters such as leaflet area, leaf area, number of branches, plant fresh weight, dry fresh weight, number of pods per plant, number of seeds per plant and seeds yield per plant. All vegetative parameters were significantly different at $p \leq 0.05$ among the spacing. The highest leaflet area, leaf area, number of branches, plant fresh weight, dry fresh weight, number of pod per plant, number of seeds per plant and seeds yield per plant were produced at $60 \times 30 \mathrm{~cm}$. Regression analyses of seeds yield with vegetative growth parameters revealed a moderate positive relationship of seeds yield with leaflet area $\left(\mathrm{R}^{2}=0.81\right)$, leaf area $\left(R^{2}=0.71\right)$, No. of branches per plant $\left(R^{2}=0.74\right)$, and plant fresh weight $\left(R^{2}=0.58\right)$, plant dry weight $\left(\mathrm{R}^{2}=0.68\right)$. Regarding yield components, seeds yield was found to have a moderate or strong positive relationship with No. of pods per plant $\left(\mathrm{R}^{2}=0.62\right)$ and number of seeds $\left(\mathrm{R}^{2}=0.96\right)$.
\end{abstract}

\section{Article Info}

Accepted: 07 September 2016

Available Online: 06 October 2016

\section{Keywords}

Groundnut

Growth

Plant spacing

Yield

\section{Introduction}

Groundnut (Arachis hypogaea L.) is a cultivated annual of South American origin, domesticated in the broad area among Brazil, Argentina, Paraguay, Peru and Bolivia (Tweneboah, 2000). Unknown outside the New World in pre-Columbus times, groundnut was first taken to the West Coast of Africa by the Portuguese in the $16^{\text {th }}$ century, while the Spanish took it to the Philippines from Peru. According to Purseglove (1998), groundnut was taken across the pacific to the Philippines by the Spaniards before spreading to Asia. Arachis hypogaea L. belongs to the family Leguminosae and sub-family Papilionoideae (Waele and Swanevelder, 2001). They also stated that the botanical name of groundnut is derived from the Greek arachis meaning 'legume' and hypogaea meaning 'below ground', referring to the formation of pods in the soil. Like the bambara groundnut of West Africa, all species of Arachis are geocarpic, opening their fruits underground and the plant is cultivated in tropical and sub tropical regions all over the world as well as warm temperate regions (Kochhar, 1986). Most of the crop is produced in regions with an annual rainfall of $400 \mathrm{~mm}$ or more under low evaporative demand but there is a minimum requirement for $200 \mathrm{~mm}$ during the growing season although this is greater in soils that do not store winter rainfall (Gibbon and Pain, 1985). A good rainfall distribution during the vegetative 
period of growth will encourage adequate flowering and proper development of the nuts (Tweneboah, 2000). Kochhar (1986) indicated that enough rainfall of 500 to $1000 \mathrm{~mm}$ per year to ensure high respiratory exchanges during pod formation and vegetative period of growth. On ideal temperature for groundnut, Tweneboah (2000) reported $24-30^{\circ} \mathrm{C}$, but a minimum of $12-15^{\circ} \mathrm{C}$ is required for germination and at least $24^{\circ} \mathrm{C}$ is necessary for flowering and seed setting.

Groundnut is the sixth most important oilseed crop in the world. It contains $48-50 \%$ oil and $26-28 \%$ protein, and is a rich source of dietary fiber, minerals, and vitamins. Groundnut is grown on 26.4 million ha worldwide with a total production of 37.1 million metric ton and an average productivity of 1.4 metric tha. Over 100 countries worldwide grow groundnut (Khidir, 1997). Developing countries constitute $97 \%$ of the global area and $94 \%$ of the global production of this crop. The production of groundnut is concentrated in Asia and Africa (56\% and $40 \%$ of the global area and 68\% and $25 \%$ of the global production, respectively). Groundnut or peanut is playing an important role in the dietary requirements of resource poor women and children, and haulms are used as livestock feed. Groundnut oil is composed of mixed glycerides and contains a high proportion of unsaturated fatty acids, in particular, oleic $(50-65 \%)$ and linoleic (18-30\%) (Young, 1996). Groundnuts are also important in the confectionery trade and the stable oil is preferred by the deep-frying industries, since it has a smoke point of $229.4^{\circ} \mathrm{C}$ compared to the $193.5^{\circ} \mathrm{C}$ of extra virgin olive oil. The oil is also used to make margarines and mayonnaise (Young, 1996).

The main problems limiting production of peanut are poor cultural practices and inadequate weed management. Groundnut cannot compete effectively with weeds, particularly 3-6 weeks after sowing; therefore, early removal of weeds is important before flowering and during pegging (Page et al., 1982). If early weeding is done well, and crop spacing recommendations followed, then the weeds that come up later are smothered with the vigorous growth of the crop. Once flowering and pegging begins it is advisable to weed by hand pulling rather than by using a hoe, as this is less likely to disturb any developing pods. Hand weeding (hoeing) is still by far the most widely practiced cultural weed control technique in field crop production throughout the tropics because of the prohibitive costs of herbicides and fear of toxic residue coupled with the lack of knowledge about their use. The objective of this study was: to investigate the effect of planting densities on groundnuts growth and yield components.

\section{Materials and methods}

Field experiment was performed at research area of Faculty of Agricultural Sciences, University of Sulaimani, during spring season of 2013 to evaluate the growth and yield performance of peanut variety under different plants spacing. The seed of groundnut (variety Sodari) was tested. Experiment was laid out in a randomized complete block design (RCBD) and each treatment was replicated three times. A net plot size of 3 $\mathrm{m} \times 1.5 \mathrm{~m}$ was kept. Three plants spacing (50x30, 60x30 and $70 \times 30 \mathrm{~cm}$ ) were used. Sowing date was on 16 April by hand. Seeds were sown on rows in hills. Three seeds were placed in each hill, which were then thinned to one plant per hill, two weeks later. NPK in the form of urea, DAP and potassium sulphate, respectively, at the rate of 60-75-30 kg ha-1 was applied. Full dose of each of nitrogen, phosphorus and potassium was applied basally. After $1^{\text {st }}$ irrigation, weeds were removed by hoeing. All other agronomic practices were kept uniform among treatments applied. The amount of water that was applied by irrigation was not available; however, irrigation was applied as needed to keep plants from showing water deficit stress. Weeding was done by hand hoeing and/ or hand pulling when weeds were tender. Weeding began two weeks after planting until peg formation, to ensure that pegs are not destroyed.

A sample of 3-5 plants was taken at random from the inner rows of each experimental unit to measure the parameters related to plant growth and yields such as, plant height, leaflet area, leaf area, number of branches per plant, number of pods per plant, plant fresh weight, plant dry weight and seeds yield, were recorded for analysis.

The data thus collected were analyzed statistically by the analysis of variance technique and treatment means were compared using Duncan test at $5 \%$ level of probability (Steel et al., 1997). To assess the relationship of seeds yield with other parameters, regression analyses were performed on XLSTAT software. The leaf and leaflet area were measured by Image Lab software.

\section{Results and discussion}

The mean squares from the analysis of variance for growth and yield of peanut are presented in (Table 1). The effect of plant or row spacing was significant for the 
agronomic characters investigated. Data of means of leaflet and leaf area of different plant spacing are given in (Tables 1 and 2). These data reveals that plant spacing $60 \times 30 \mathrm{~cm}$ produced significantly highest leaflet and leaf area $\left(8.33\right.$ and $\left.27.3 \mathrm{~cm}^{2}\right)$. However, lowest leaflet and leaf area $\left(4\right.$ and $\left.15.1 \mathrm{~cm}^{2}\right)$ were observed in plant spacing $50 \times 30 \mathrm{~cm}$ which was statistically identical with plant spacing $70 \times 30 \mathrm{~cm}$. The reduced competition and increased availability of resources like nutrients, soil moisture and light paved way for higher leaf area per plant (leaf area). Results of the number of branches at all the sampling days are presented in (Table 2). There was a significant difference $(p<0.05)$ between the number of branches produced by plant spacing $50 \times 30 \mathrm{~cm}$ and $60 \times 30$ $\mathrm{cm}$ where the effect of plant spacing $60 \times 30 \mathrm{~cm}$ produced greater number of branches. Difference between the effect of $60 \times 30 \mathrm{~cm}$ and $70 \times 30 \mathrm{~cm}$ was not significant. However, Suzuki and Furukawa (1958) and El Naim et al. (2010) found that, at a close spacing the branches develop less in number than at wider spacing. This result may be attributed to vigorous plant with less competition for light, nutrients.

Table 1. Mean square values from the analysis of variance for growth and yield of peanut.

\begin{tabular}{lllllllll}
\hline Source & $\begin{array}{l}\text { Leaflet } \\
\text { area }\left(\mathbf{c m}^{\mathbf{2}}\right)\end{array}$ & $\begin{array}{l}\text { Leaf area } \\
\left(\mathbf{c m}^{\mathbf{2}}\right)\end{array}$ & $\begin{array}{l}\text { No. of } \\
\text { branches/ } \\
\text { plant }\end{array}$ & $\begin{array}{l}\text { Fresh weight/ } \\
\text { plant } \mathbf{( g )}\end{array}$ & $\begin{array}{l}\text { Dry weight/ } \\
\text { plant }(\mathbf{g})\end{array}$ & $\begin{array}{l}\text { No. of } \\
\text { pods/ plant }\end{array}$ & $\begin{array}{l}\text { No. of } \\
\text { seeds/ plant }\end{array}$ & $\begin{array}{l}\text { Seeds yield/ } \\
\text { plant }(\mathbf{g})\end{array}$ \\
\hline Block & 0.444 & 3.111 & 7 & 78.111 & 33.444 & 0.333 & 8.444 \\
Plant spacing & $14.778^{*}$ & $109.778^{* *}$ & $7 *$ & $263.111^{* *}$ & $328.444 * *$ & $112.333 * *$ & $1005.778 * *$ & $324.778^{* * *}$ \\
Error & 1.111 & 2.111 & 1 & 21.111 & 11.611 & 0.667 & 2.111 & 0.611 \\
\hline
\end{tabular}

Table 2. Effect of plant spacing on growth and yield characters in peanut

\begin{tabular}{lllllllll}
\hline $\begin{array}{l}\text { Plant } \\
\text { spacing }\end{array}$ & $\begin{array}{l}\text { Leaflet area } \\
\left(\mathbf{c m}^{\mathbf{2}}\right)\end{array}$ & $\begin{array}{l}\text { Leaf area } \\
\left(\mathbf{c m}^{\mathbf{2}}\right)\end{array}$ & $\begin{array}{l}\text { No. of branches/ } \\
\text { plant }\end{array}$ & $\begin{array}{l}\text { Fresh weight/ } \\
\text { plant }\end{array}$ & $\begin{array}{l}\text { Dry weight/ } \\
\text { plant }(\mathbf{g})\end{array}$ & $\begin{array}{l}\text { No. of pods/ } \\
\text { plant }\end{array}$ & $\begin{array}{l}\text { No. of } \\
\text { seeds/ } \\
\text { plant }\end{array}$ & $\begin{array}{l}\text { Seeds } \\
\text { yield }(\mathbf{g}) / \\
\text { plant }\end{array}$ \\
\hline $50 \times 30$ & $4 \mathrm{~b}$ & $15.1 \mathrm{~b}$ & $11.67 \mathrm{~b}$ & $135.1 \mathrm{~b}$ & $62.65 \mathrm{~b}$ & $3.69 \mathrm{~b}$ & $4.1 \mathrm{c}$ \\
$60 \times 30$ & $8.33 \mathrm{a}$ & $27.3 \mathrm{a}$ & $14.68 \mathrm{a}$ & $153.68 \mathrm{a}$ & $82.68 \mathrm{a}$ & $2.68 \mathrm{c}$ & $15 \mathrm{a}$ & $39.35 \mathrm{a}$ \\
$70 \times 30$ & $5.33 \mathrm{~b}$ & $22.33 \mathrm{~b}$ & $12.64 \mathrm{ab}$ & $143.2 \mathrm{~b}$ & $78 \mathrm{a}$ & $13.35 \mathrm{a}$ & $13.4 \mathrm{~b}$ & $5.7 \mathrm{~b}$ \\
\hline
\end{tabular}

Similar letters are not significantly different at the 0.05 level of probability according to Duncan Multiple Range Test.

The plant fresh weight is presented in (Table 2). Plant spacing did significantly affect $(p \leq 0.05)$ on plant fresh weight. Plant spacing $60 \times 30 \mathrm{~cm}$ produced the highest plant fresh weight (153.68). This result may be due to less competition of plants for water uptake. This result is not in agreement with Naeem et al. (2007) reported that among different row spacing, the highest yield was recorded at spacing of $30 \times 15 \mathrm{~cm}$. The plant spacing produced significant differences in plant dry weight at $5 \%$ probability level. Among the plant spacing, $60 \times 30$ $\mathrm{cm}(82.68 \mathrm{~g})$ had the highest plant dry weight which was significantly higher than $50 \times 30 \mathrm{~cm}(62.65 \mathrm{~g})$. The plant dry weight of $70 \times 30 \mathrm{~cm}$ was not significantly different. The results on filled and unfilled number of pods per plants are presented in (Table 2). There was significant difference between $60 \times 30 \mathrm{~cm}$ and $50 \times 30 \mathrm{~cm}$ in the number of pods at $5 \%$ level of probability. The maximum number of pods per plant was observed by plant spacing $60 \times 30 \mathrm{~cm}(15)$ while the minimum was recorded by $50 \times 30 \mathrm{~cm}$ (3.69). The plant spacing showed significant differences in plant dry weight at 5\% probability level plant spacing $60 \times 30 \mathrm{~cm}$ contributed to increasing in number of seeds per plant (39.35). This was in disagreement with spacing at $30 \times 15$ observation made by Chandrasekaran et al. (2007) who reported $20 \mathrm{~kg}$ $\mathrm{P} / \mathrm{ha}$. Maximum seeds yield per plant (21.1 g) was observed in $60 \times 30 \mathrm{~cm}$ while the minimum seeds yield was shown by $50 \times 30 \mathrm{~cm}(2.68 \mathrm{~g})$ (Table 2$)$.

Regression analyses as presented in Figs. 1, 2, 3, 4, 5, 6 and 7 indicate a significant relationships of seeds yield with leaflet and leaf area, number of branches per plant, plant fresh weight, plant dry weight, number of pods per plant, and number of seeds per plant at $5 \%$ probability level. Regression analyses of seeds yield with vegetative growth parameters revealed a moderate positive relationship of seed yield with leaflet are $\left(\mathrm{R}^{2}=0.81\right)$, leaf area $\left(\mathrm{R}^{2}=0.71\right)$, No. of branches per plant $\left(\mathrm{R}^{2}=0.74\right)$, and plant fresh weight $\left(\mathrm{R}^{2}=0.58\right)$, plant dry weight $\left(\mathrm{R}^{2}=0.68\right)$. As regards yield components, seed yield was found to have a moderate or strong positive relationship with No. of pod per plant $\left(\mathrm{R}^{2}=0.62\right)$ and number of seeds $\left(\mathrm{R}^{2}=0.96\right)$. Among regression analyses of seed yield with all parameters studied, highest value of regression coefficient $(b=3.9)$ was observed with leaflet area (Fig. 1), whereas lowest value of regression coefficient $(b=0.0016)$ was seen with plant fresh weight (Fig. 4). 


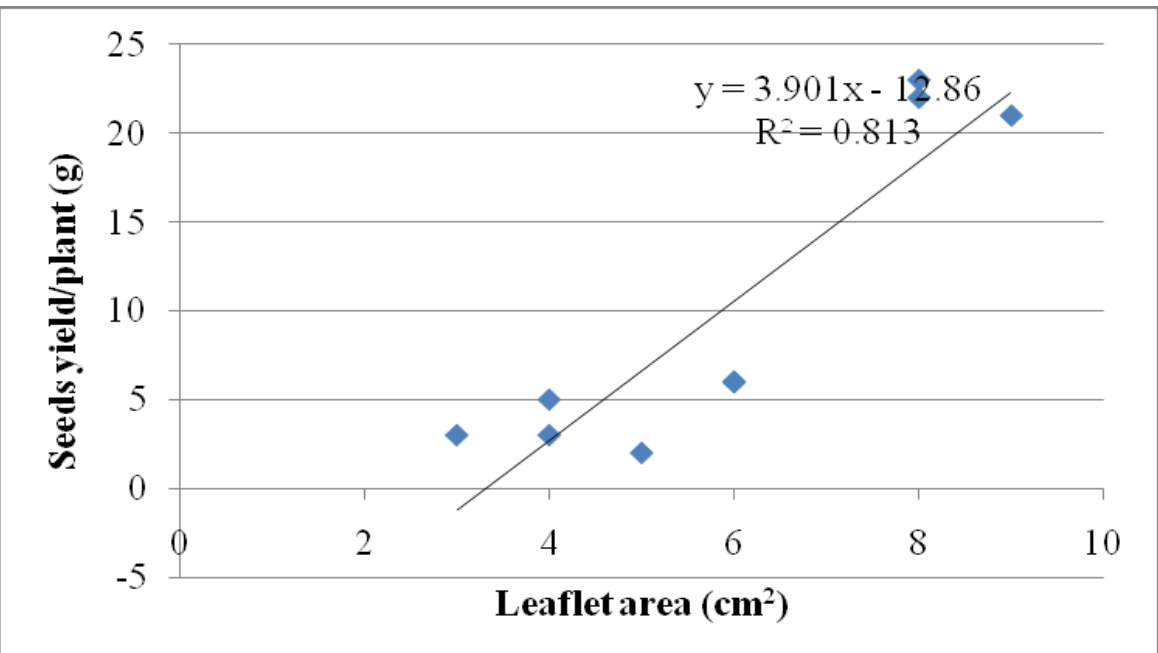

Fig. 1: Regression analysis of seed yield as affected by leaflet area $\left(\mathrm{cm}^{2}\right)$.

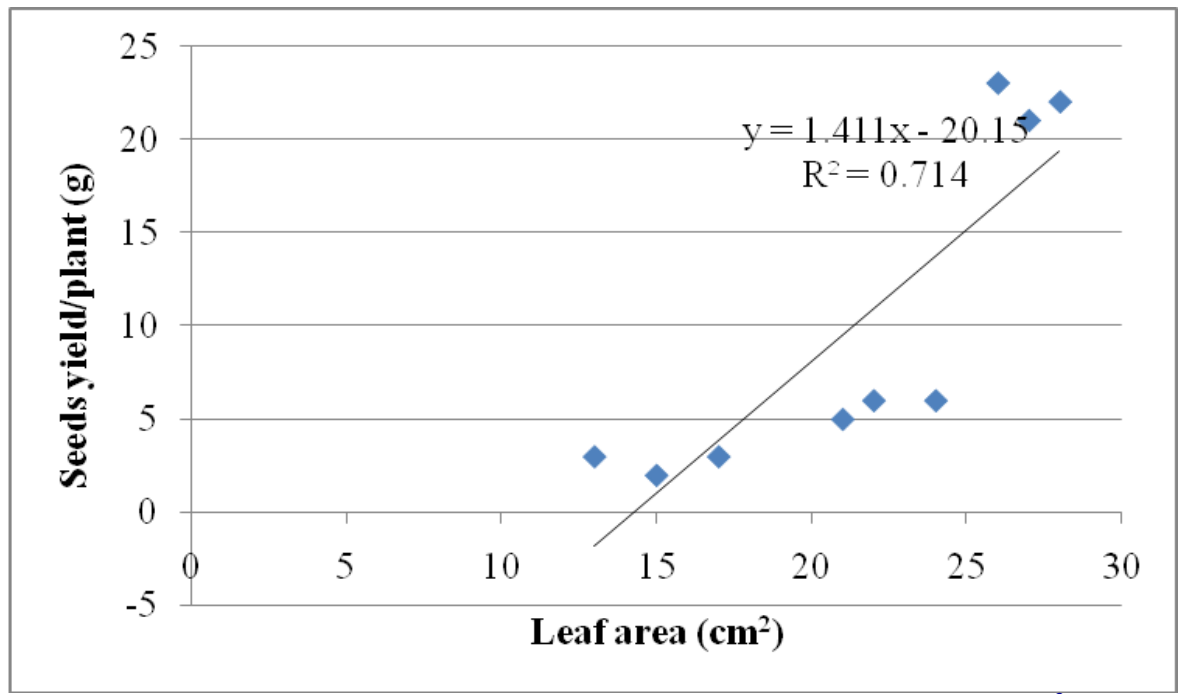

Fig. 2: Regression analysis of seed yield as affected by leaf area $\left(\mathrm{cm}^{2}\right)$.

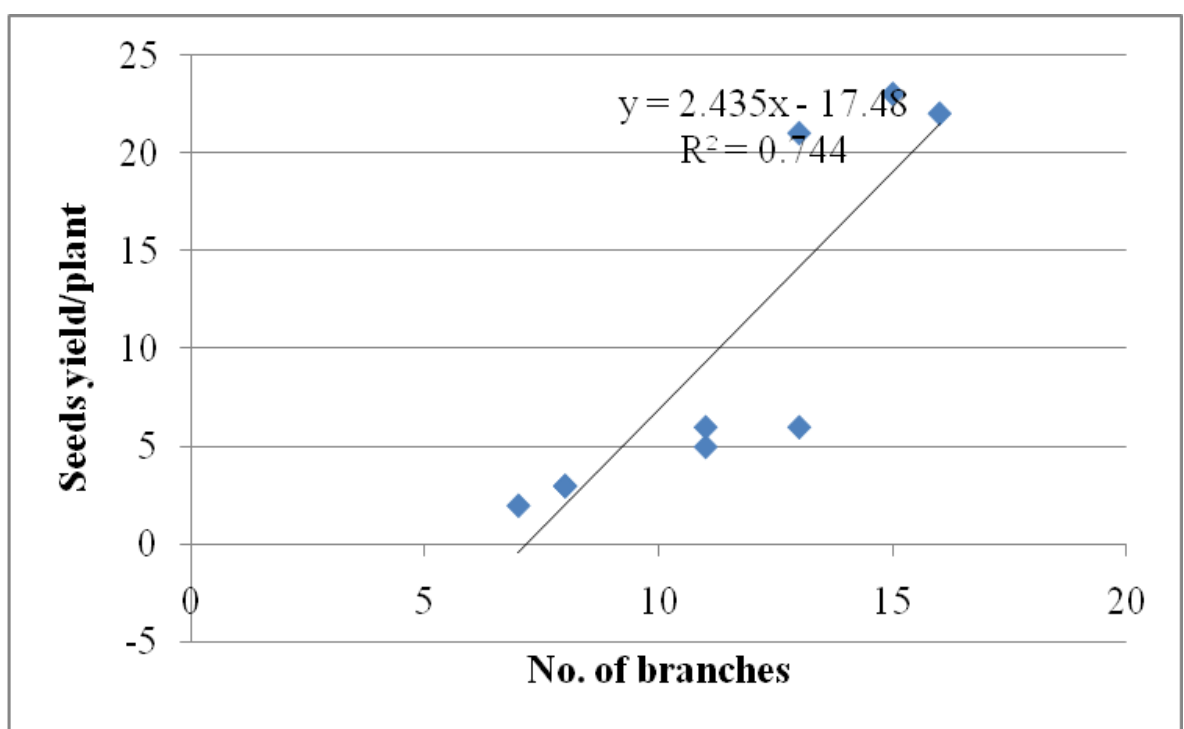

Fig. 3: Regression analysis of seed yield as affected by number of branches. 


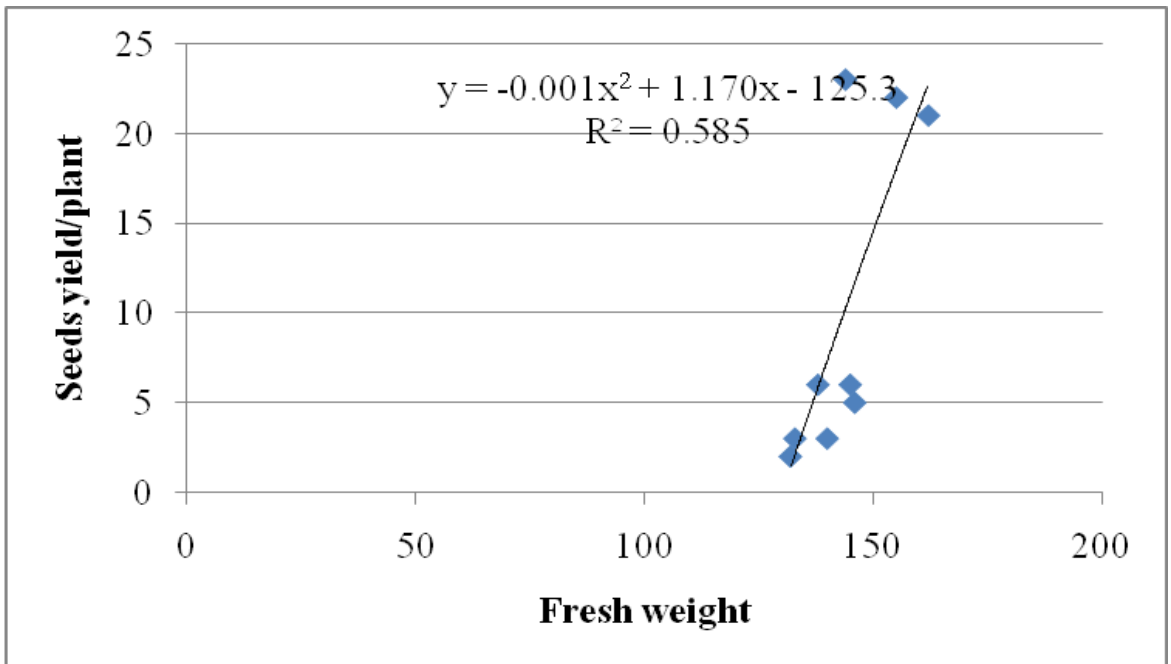

Fig. 4: Regression analysis of seed yield as affected by plant fresh weight (g).

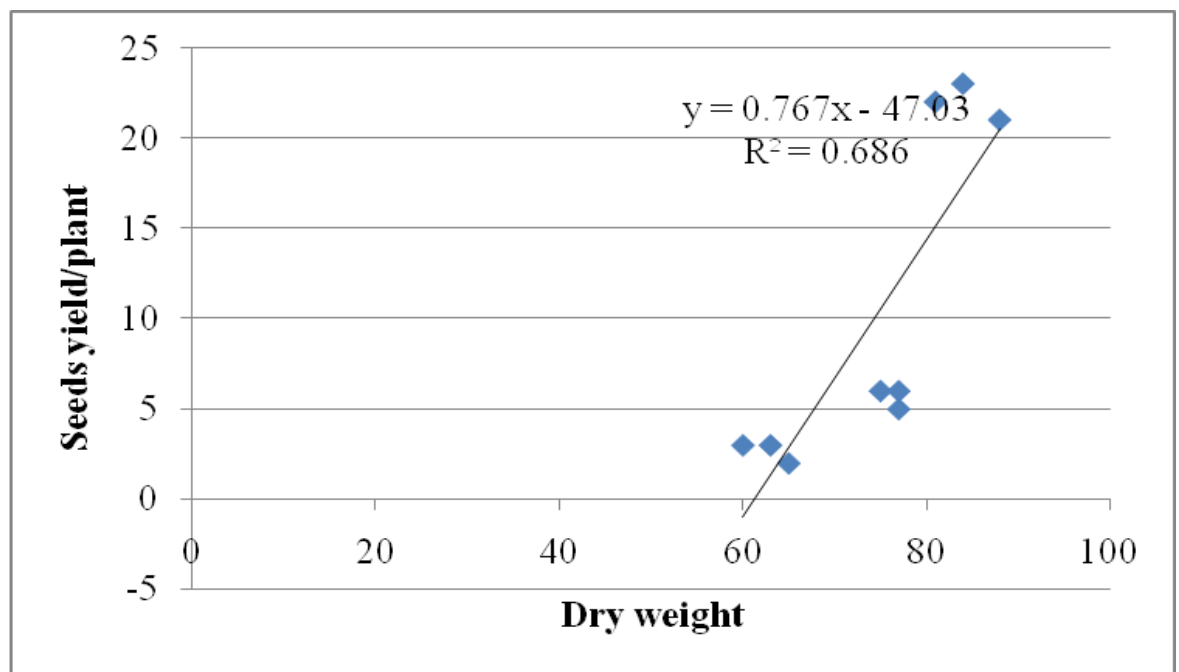

Fig. 5: Regression analysis of seed yield as affected by plant dry weight (g).

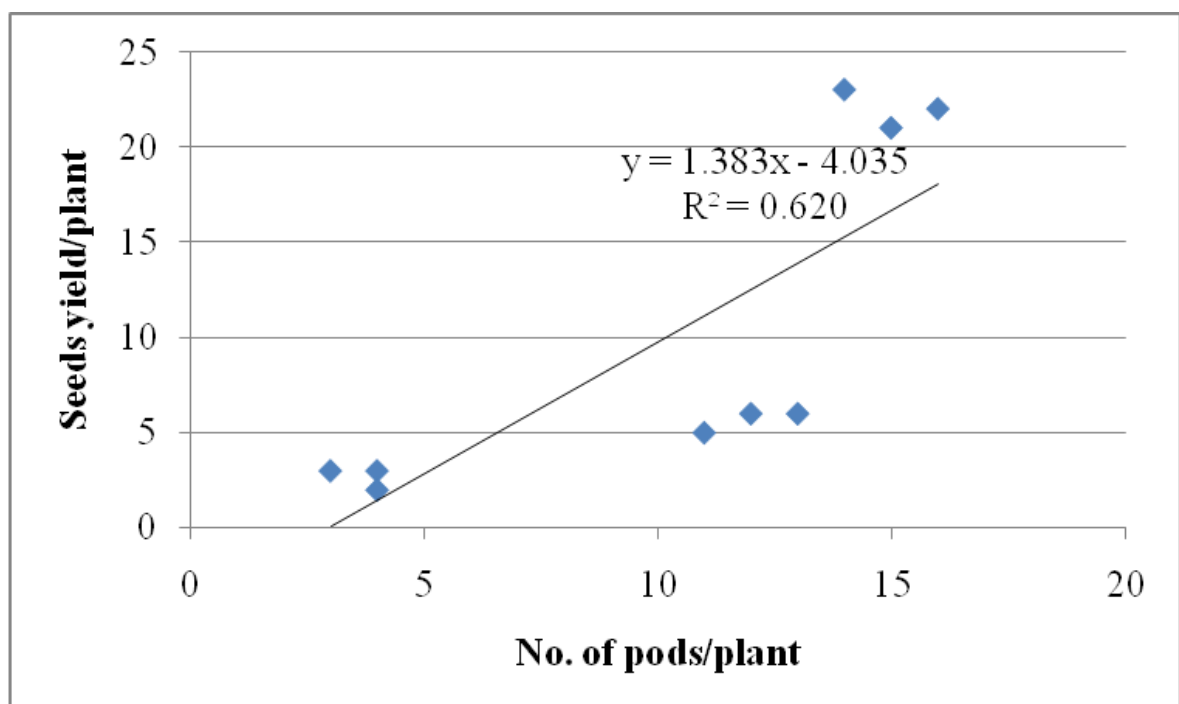

Fig. 6: Regression analysis of seed yield as affected by number of pods per plant. 


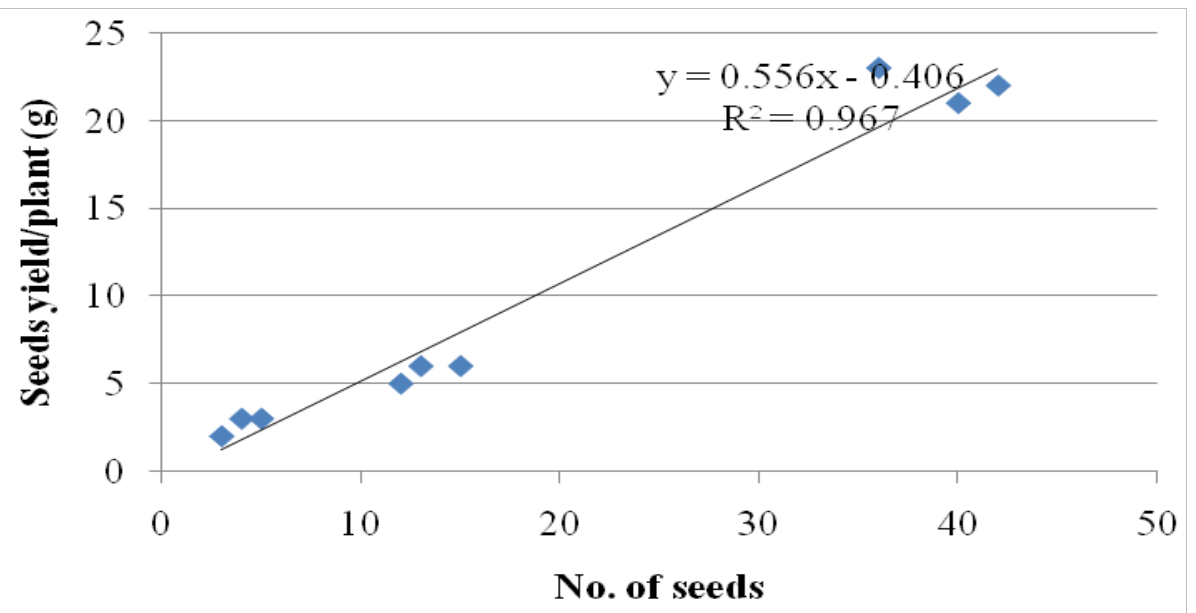

Fig. 7: Regression analysis of seed yield as affected by number of seeds per plant.

\section{Conclusion}

Out of all the plant spacing studied, plant spacing60x30 $\mathrm{cm}$ performed best with respect to seed yield and yield contributing traits therefore it is proved to be most suitable for sowing under agro-climatic conditions of Bakrajo. However, plant spacing $50 \times 30 \mathrm{~cm}$ was found to be inferior to all other plant spacing. All the plant traits positively contributed towards final seeds yield. However maximum contribution was given by leaflet area. Therefore, these traits should be given top priority when breeding was aimed at selecting superior peanut genotypes. However, minimum contribution was given by plant fresh weight therefore this trait should be given least importance.

\section{Conflict of interest statement}

Authors declare that they have no conflict of interest.

\section{References}

Chandrasekaran, E. M., Somasundaram, M., Amanullah, K., Thirukumaran, K., Sathyamoorthi, K., 2007. Influence of varieties and plant spacing on the growth and yield of confectionery groundnut (Arachis hypogaea L.). India. Res. J. Agric. Biol. Sci. 3(5), 525-528.

El Naim, A. M., Eldouma, M. A., Abdalla, A. E., 2010. Effect of weeding frequencies and plant population on vegetative growth characteristic in groundnut (Arachis hypogaea L.) in North Kordofan of Sudan. Int. J. Appl. Biol.
Pharmaceut. Technol. 1(3), 1188-1193.

Gibbon, D., Pain, A., 1985. Crops of the Drier Regions of the Tropics. Longman Group UK Limited. pp.120-127.

Khidir (1997). Oil seed crops in the Sudan. Khartoum University Press, Khrtoum, Sudan.

Kochhar, S. L., 1986. Tropical Crops- A Textbook of Economic Botany. MacMillan Publishers Ltd. 157p.

Naeem, A, Mohammed, R, Khan, U., 2007. Evaluation of different varieties, seed rates and row spacing of groundnut planted under agro-ecological conditions of Makaland Division. J. Agron. 6(2), 385-387.

Page, A.L., Miller, R.H., Keeney, D.R., 1982. Methods of soil analysis. Part 2. Chemical and Microbiological Properties. $2^{\text {nd }}$ Edn. American Society of Agronomy and Soil Science Society of America. Madison, Wisconsin, USA. pp.416-418.

Purseglove, J.W., 1998. Tropical Crops-Dicotyledon. Longman. pp.225-235.

Steel, R.G.D., Torrie, J.H., Dickey, D.A., 1997. Principles and Procedures of Statistics, A Biometrical Approach. $3^{\text {rd }}$ Edn. McGraw-Hill Co. Inc., New York.

Susuki, M., Furukava, Y., 1958. Studies on plant spacing of peanut. Tech. Bull. Facult. Hortic. (Ghib University). 6, 164-150.

Suzuki, M., Furukawa, Y., 1958. Studies on plant spacing of peanut. Chiba Univ. Tech. Bull. No. 6. pp.145-150.

Tweneboah, C. K., 2000. Modern Agriculture of the Tropics with Special Reference to Ghana. Cp-Wood Publisher. pp.189-190.

Waele, D., Swanevelder, C.J., 2001. Crop production in tropical Africa. Goikink Graphic nv. Belgium. pp.747753.

Young, C., 1996. Peanut Oil. Bailey's Industrial Oil and Fat Product. 2, 337-392.

\section{How to cite this article:}

Hamakareem, H. F., Hamahasan, B. M., Salih Ali, S. H., 2016. Influence of plant spacing on the growth and yield of groundnut (Arachis hypogaea L.). Int. J. Curr. Res. Biosci. Plant Biol. 3(10), 7-12. doi: http://dx.doi.org/10.20546/ijcrbp.2016.310.002 